\title{
Evaluation of Juvenile Growth, Feed Efficiency and Body Conformation Traits of Native $\times$ CSFL Crossbred Chicken under Intensive System of Rearing
}

\section{Shyam Sundar Pandey ${ }^{1}$, Nrusingha Charan Behura ${ }^{1}$, Lipismita Samal ${ }^{1 *}$, Prasad Kumar Pati ${ }^{2}$ and Ganga Dhara Nayak ${ }^{3}$}

\author{
${ }^{1}$ Department of Poultry Science, ${ }^{2}$ Department of Livestock Products and Technology, \\ ${ }^{3}$ Department of Animal Breeding and Genetics, College of Veterinary Science and Animal \\ Husbandry, Orissa University of Agriculture and Technology, \\ Bhubaneswar-751003, Odisha, India \\ *Corresponding author
}

\section{Keywords}

Crossbred chicken, Growth performance, Body conformation traits, Intensive system

Article Info

Accepted:

22 April 2018

Available Online: 10 May 2018

\section{A B S T R A C T}

A study was conducted to evaluate the performance of Native $\times$ CSFL F1 crossbred chicks up to 8 weeks of age under intensive management system. Ninety (90) chicks were used for this study. Body weight and feed intake were recorded weekly. The body conformation traits were measured at $6^{\text {th }}$ and $8^{\text {th }}$ weeks of age. The $8^{\text {th }}$ week body weight of males and females were $1016.97 \pm 45.13 \mathrm{~g}$ and $830.33 \pm 19.64 \mathrm{~g}$ respectively. The weekly feed conversion ratio (FCR) increased progressively from $1.50 \pm 0.08$ at $1^{\text {st }}$ week to $4.38 \pm 0.89$ at $8^{\text {th }}$ week of age. The $8^{\text {th }}$ week cumulative FCR was $3.23 \pm 0.15$. At $6^{\text {th }}$ week of age, all recorded linear body measurements were higher in male chicks than the female chicks except body girth. At $8^{\text {th }}$ week of age, body girth, shank length, shank width and head width were significantly $(\mathrm{P} \leq 0.05)$ higher in male chicks than that of female chicks. From this study, it was concluded that the Native $\times$ CSFL F1 crossbred chickens could be reared profitably under intensive system of management because of its high $8^{\text {th }}$ week body weight and low FCR. Further, the cross being developed using local native germplasm, the birds could thrive and perform better in local climatic conditions in rural small scale farming. 


\section{Introduction}

Backyard poultry sector plays a significant role in improving the socio-economic status of rural people by generating employment opportunity and augmenting family income particularly among landless laborers, small and marginal farmers and women in rural areas. The native chickens are highly adapted to the local climatic conditions and are highly resistant to adverse climate and endemic diseases. However, the native chickens are poor performers in terms of growth when compared to improved commercial chicken varieties. In order to increase the productivity of backyard chicken, introducing improved "low technology inputs birds" is necessary. Crossbreeding could lead to production of birds that will be better in growth rate, efficiency of feed conversion and reproductive traits without sacrificing adaptability to the local environment (Adebambo et al., 2011). Crossbred poultry have higher feed efficiency and lower mortality rate as compared to purebreds, which in turn play a very important role in increasing profits in poultry production (Dwivedi et al., 1986). To utilize the good adaptive characteristics of the native chickens and possibly exploit the phenomenon of heterosis, crossbreeding programmes of native chickens with suitable exotic stocks would be more appreciable. Considering the necessity to develop potential poultry crossbreds, suitable for backyard farming as well as commercial farming, the present study was designed to evaluate the performance of the crosses of a native and coloured broiler parent line in respect to their juvenile growth, feed conversion efficiency and body conformation traits under intensive system management.

\section{Materials and Methods}

The study was carried out at PG Department of Poultry Science, College of Veterinary Science and Animal Husbandry, Orissa
University of Agriculture and Technology, Bhubaneswar.

\section{Experimental animals}

Adult coloured synthetic female line (CSFL) females and males of a native population were used to develop the F1 cross. Five native males and 40 CSFL females were housed in breeding pens in the ratio of $8: 1$, to produce fertile eggs. The eggs were incubated to produce $\mathrm{F} 1$ progenies which were maintained up to 8 weeks of age under intensive system of management for evaluation.

\section{Housing and management}

Ninety (90) day-old Native $\times$ CSFL F1 crossbred chicks were randomly distributed into three replicate groups and housed separately. All the chicks were wing banded and day-old body weights were recorded. The chicks were brooded for 3 weeks and reared under intensive system on deep litter in conventional open-sided house and similar management practices were followed for all the chicks throughout the experimental period. Proper floor space, feeder space and waterer space was given according to their body weight and age. Routine medication and vaccination procedures were followed for all the experimental birds. A starter diet with $20 \%$ $\mathrm{CP}$ and $2600 \mathrm{kcal} \mathrm{ME} / \mathrm{kg}$ was prepared and fed to the chicks ad libitum. Clean and fresh water was made available to the birds all the time.

\section{Data collection}

Body weight of birds was recorded individually at day-old followed by weekly intervals up to 8 weeks of age using a digital electronic balance nearest to $1.0 \mathrm{~g}$ accuracy. The body weight gain was calculated by subtracting the initial body weight from final body weight of the periods and cumulative 
gains for successive weeks were calculated. The feed consumption of the experimental birds was recorded replicate-wise on weekly basis by subtracting the residual feed at the end of the week from total feed offered during the week. Cumulative feed intake (g/bird) was calculated by dividing total feed intake by the birds up to a particular week from number of birds. Weekly feed conversion ratio (FCR) was calculated from weekly body weight gain and weekly feed consumed. Similarly, cumulative FCR was calculated from cumulative body weight gain and cumulative feed consumed. Except breast angle which was measured by goniometer, all other body conformation traits such as beak length, head width, breast angle, shank length, shank width, body length, height, girth and keel length were recorded using measuring tapes (calibrated in centimetres) at $6^{\text {th }}$ and $8^{\text {th }}$ weeks of age as described elsewhere (Nandi et al., 2017).

\section{Statistical analysis}

Data collected on various parameters were subjected to statistical analysis using Statistical Analysis System (SAS, 2009) version 9.2.1. The results were presented as least square means \pm standard error and means separation was done by using t-test (Paired sample). The difference between means was declared significant at $\mathrm{P} \leq 0.05$.

\section{Results and Discussion}

\section{Body weight and weight gain}

The mean day-old and weekly body weight of Native $\times$ CSFL F1 crossbred chicks up to 8 weeks of age have been presented in Table 1 . The mean day-old body weight of Native $x$ CSFL F1 crossbred chicks $(40.64 \pm 0.37 \mathrm{~g})$ was found to be higher than BN cross $(31.50 \mathrm{~g})$ and BND cross $(33.52 \mathrm{~g})$ as reported by Guwahati Rural Poultry Centre as well as BN cross $(30.37 \mathrm{~g})$ and DBN cross $(32.36 \mathrm{~g})$ as reported by Ranchi Rural Poultry Centre (AICRP Annual Report, 2013-2014). The day-old BW of Native $\times$ CSFL F1 crossbred was also higher than Hansli $\times$ CSML (36.60 $\pm 2.23 \mathrm{~g})$ as reported by Ekka et al., (2016), Dahlem Red (33.24g), Dahlem red $\times$ Desi $(32.67 \mathrm{~g})$ as reported by Jha et al., (2013), PD1×PD4 (32.11 g) as reported by Padhi et al., (2014) and PB2 X Indigenous (29.65g) as reported by Kalita et al., (2011).

The $4^{\text {th }}$ week body weight of the crossbred under study, on combined sex basis was $350.20 \pm 5.76$ g. Kalita et al., (2011) reported a lower value $(210.58 \mathrm{~g})$ for $4^{\text {th }}$ week body weight of PB $2 \times$ Indigenous. The $4^{\text {th }}$ week body weight of Native $\times$ CSFL F1 crossbred chicks was comparable with the $4^{\text {th }}$ week body weight of Vanaraja $(316.47 \pm 2.47 \mathrm{~g})$ as reported by Jha and Prasad (2013). The $6^{\text {th }}$ week body weight of Native $\times$ CSFL F1 crossbred chicks on combined sex basis was $706.45 \pm 31.42 \mathrm{~g}$, which was higher than that of PD1 $\times$ PD4 (380.63 g) as reported by Padhi et al., (2014) and Vanaraja $(625.0 \pm 10.90 \mathrm{~g}$ and $629.23 \pm 4.02 \mathrm{~g}$ ) as reported by Jha et al., (2013) and Kumaresan et al., (2008) respectively but lower than that of Hansli $x$ CSML (793.83 g) as reported by Ekka et al., (2016).

The $8^{\text {th }}$ week body weight of crossbred under study on combined sex basis was 923.64 $\pm 47.18 \mathrm{~g}$ which was much higher than that of Dahlem Red (495.46g), Dahlem Red $\times$ Desi $(428.23 \mathrm{~g})$ and PD1 $\times$ PD4 (380.63g) as reported by Jha et al., (2013) and Padhi et al., (2014) but lower than that of Hansli $\times$ CSML $(1159.45 \pm 49.09 \mathrm{~g})$ as reported by Ekka et al., (2016). The $8^{\text {th }}$ week BW of Native $\times$ CSFL F1 crossbred chicks was also higher than that of Australop $\times$ Tswana (male-727.61g, female- $634.30 \mathrm{~g}$ ) as reported by Kgwatalala and Segokgo (2013) and RIR $\times$ Fayoumi (Khawaja et al., 2012). As reported by Adedokun and Sonaiya (2002), Chatterjee et 
al., (2002), Kalita et al., (2011) and Padhi et al., (2015), the $8^{\text {th }}$ week body weight of various broiler native crosses were $468 \pm 33.1 \mathrm{~g}$, $413 \pm 8.12 \mathrm{~g}, \quad 670.83 \mathrm{~g}$ and $\quad 721.73 \pm 15.20 \mathrm{~g}$ respectively. It was found that the $8^{\text {th }}$ week body weight of Native $\times$ CSFL F1 crossbred chicks was much higher than the above reported values for various broiler native crosses.

The $8^{\text {th }}$ week body weight of the crossbred under present study was comparable with Vanaraja $(832.5 \pm 4.53 \mathrm{~g})$ and $\mathrm{PB} 2 \times$ Native cross (853.31g) as reported by Jha et al., (2012). The body weight gain during different stages of growth exhibited a similar trend as that of body weight (Table 2 ).

Growth is a function of gene and environment. The difference in body weight of the crossbred in the present investigation as compared with other crosses could be attributed to the genetic potential of the lines/populations used to develop the cross which vary widely besides the difference in the nutritive values of the feed offered. The body weight of the crossbred in the present study indicates that the Native $x$
CSFL F1 crossbred chicken has a good growth potential.

\section{Feed conversion ratio}

The weekly and cumulative FCR of Native $x$ CSFL F1 crossbred chicks on combined sex basis have been presented in Table 3. The weekly FCR gradually increased with increase in age. The $5^{\text {th }}$ week FCR of crossbred under study was recorded as $2.10 \pm 0.10$. The $5^{\text {th }}$ week FCR as reported by Ekka et al., (2016) for Hansli $\times$ CSML cross was 2.05 which were similar to the FCR value obtained in the present investigation. The $5^{\text {th }}$ week FCR value obtained in the present experiment was lower than that of PB2 $\times$ Indigenous (2.72), Dahlem red $\times$ Native (2.75) and Kamrupa (2.81) which indicated better feed conversion efficiency of the crossbred under study. The $5^{\text {th }}$ week FCR of BN crosses and BDN crosses of Guwahati centre were reported as 3.28 and 2.86 respectively and that of $\mathrm{ND} \times \mathrm{D}$ crosses was reported as 2.68 (AICRP Annual Report, 2013-2014) which were higher than the $5^{\text {th }}$ week FCR of Native $\times$ CSFL F1 crossbred chicks.

Table.1 Weekly body weight (mean \pm SE) of native $\times$ CSFL crossbred chicks

\begin{tabular}{|c|c|c|c|c|}
\hline \multirow{2}{*}{ Age } & \multicolumn{3}{|c|}{ Body weight $(\mathrm{g})$} & P value \\
\cline { 1 - 5 } & Male & Female & Combined sex & \\
\hline Day-old & $40.8 \pm 0.54$ & $40.47 \pm 0.52$ & $40.64 \pm 0.37$ & 0.89 \\
\hline $\mathbf{1}^{\text {st }}$ week & $74.67 \pm 1.28$ & $71.16 \pm 1.57$ & $72.89 \pm 1.03$ & 0.23 \\
\hline $2^{\text {nd }}$ week & $140.12 \pm 2.71$ & $131.40 \pm 2.94$ & $135.71 \pm 2.04$ & 0.10 \\
\hline 3 $^{\text {rd }}$ week & $240.12^{\mathrm{a}} \pm 4.58$ & $205.47^{\mathrm{b}} \pm 6.24$ & $222.59 \pm 4.30$ & 0.00 \\
\hline $\mathbf{4}^{\text {th }}$ week & $376.12^{\mathrm{a}} \pm 7.70$ & $324.88^{\mathrm{b}} \pm 6.60$ & $350.20 \pm 5.76$ & 0.00 \\
\hline $\mathbf{5}^{\text {lh }}$ week & $549.17^{\mathrm{a}} \pm 10.34$ & $463.72^{\mathrm{b}} \pm 8.36$ & $505.94 \pm 8.08$ & 0.00 \\
\hline $\mathbf{6}^{\text {th }}$ week & $770.38 \pm 7.00$ & $642.52 \pm 28.32$ & $706.45 \pm 31.42$ & 0.09 \\
\hline $\mathbf{7}^{\text {th }}$ week & $918.21 \pm 12.04$ & $765.45 \pm 30.54$ & $841.83 \pm 37.18$ & 0.08 \\
\hline $\mathbf{8}^{\text {th }}$ week & $1016.97 \pm 45.13$ & $830.33 \pm 19.64$ & $923.64 \pm 47.18$ & 0.10 \\
\hline
\end{tabular}

Means with different superscripts in a row differ significantly $(\mathrm{P} \leq 0.05)$ 
Table.2 Weekly body weight gain (mean \pm SE) of Native $\times$ CSFL crossbred chicks

\begin{tabular}{|c|c|c|c|c|}
\hline \multirow{2}{*}{$\begin{array}{c}\text { Age } \\
\text { (week) }\end{array}$} & \multicolumn{3}{|c|}{ Body weight gain $(\mathrm{g})$} & P value \\
\hline $1^{\text {st }}$ & Male & Female & Combined sex & \\
\hline $2^{\text {nd }}$ & $33.85 \pm 1.14$ & $30.69 \pm 1.44$ & $32.25 \pm 0.93$ & 0.24 \\
\hline $3^{\text {rd }}$ & $65.45 \pm 2.05$ & $60.23 \pm 1.82$ & $62.81 \pm 1.39$ & 0.17 \\
\hline $4^{\text {th }}$ & $100.00^{\mathrm{a}} \pm 2.74$ & $74.07^{\mathrm{b}} \pm 5.14$ & $86.88 \pm 3.24$ & 0.00 \\
\hline $5^{\text {th }}$ & $136.00 \pm 4.75$ & $119.41 \pm 6.79$ & $127.61 \pm 4.23$ & 0.14 \\
\hline $6^{\text {th }}$ & $173.08^{\mathrm{a}} \pm 5.02$ & $138.83^{\mathrm{b}} \pm 3.34$ & $155.74 \pm 3.52$ & 0.00 \\
\hline $7^{\text {th }}$ & $221.21 \pm 7.56$ & $167.76 \pm 9.57$ & $194.48 \pm 13.14$ & 0.09 \\
\hline $8^{\text {th }}$ & $147.83 \pm 13.14$ & $122.93 \pm 13.21$ & $135.38 \pm 10.69$ & 0.51 \\
\hline
\end{tabular}

Means with different superscripts in a row differ significantly $(\mathrm{P} \leq 0.05)$

Table.3 Weekly and cumulative feed conversion ratio (mean \pm SE) of

Native $\times$ CSFL crossbred chicks

\begin{tabular}{|c|c|c|}
\hline Age (week) & Weekly FCR & Cumulative FCR \\
\hline $1^{\text {st }}$ & $1.50 \pm 0.08$ & $1.50 \pm 0.08$ \\
\hline $2^{\text {nd }}$ & $1.74 \pm 0.06$ & $1.60 \pm 0.12$ \\
\hline $3^{\text {rd }}$ & $1.96 \pm 0.11$ & $1.80 \pm 0.70$ \\
\hline $4^{\text {th }}$ & $2.04 \pm 0.09$ & $1.90 \pm 0.05$ \\
\hline $5^{\text {th }}$ & $2.54 \pm 0.12$ & $2.10 \pm 0.10$ \\
\hline $6^{\text {th }}$ & $2.69 \pm 0.05$ & $2.69 \pm 0.05$ \\
\hline $7^{\text {th }}$ & $3.83 \pm 0.23$ & $3.13 \pm 0.05$ \\
\hline $8^{\text {th }}$ & $4.38 \pm 0.89$ & $3.23 \pm 0.15$ \\
\hline
\end{tabular}

Table.4 Linear body measurements (mean \pm SE) of Native $\times$ CSFL crossbred chicks

\begin{tabular}{|c|c|c|c|c|c|}
\hline Traits & Age $($ week & Male & Female & T value & P value \\
\hline $\begin{array}{c}\text { Breast angle } \\
\text { (degree) }\end{array}$ & $6^{\text {th }}$ & $61.57^{\mathrm{a}} \pm 1.60$ & $59.00^{\mathrm{b}} \pm 1.09$ & 1.59 & 0.00 \\
\hline Beak length & $8^{\text {th }}$ & $62.53 \pm 1.34$ & $62.30 \pm 1.22$ & 0.13 & 0.89 \\
\hline (cm) & $6^{\text {th }}$ & $3.12^{\mathrm{a}} \pm 0.02$ & $2.80^{\mathrm{b}} \pm 0.07$ & 3.73 & 0.00 \\
\hline Head width & $8^{\text {th }}$ & $3.46 \pm 0.04$ & $3.30 \pm 0.06$ & 1.56 & 0.14 \\
\hline (cm) & $6^{\text {th }}$ & $2.90^{\mathrm{a}} \pm 0.04$ & $2.43^{\mathrm{b}} \pm 0.59$ & 5.99 & 0.00 \\
\hline Body length & $8^{\text {th }}$ & $3.33^{\mathrm{a}} \pm 0.03$ & $2.73^{\mathrm{b}} \pm 0.08$ & 7.29 & 0.00 \\
\hline (cm) & $6^{\text {th }}$ & $31.57^{\mathrm{a}} \pm 0.40$ & $29.35^{\mathrm{b}} \pm 0.48$ & 3.39 & 0.00 \\
\hline Body girth $(\mathrm{cm})$ & $8^{\text {th }}$ & $35.40 \pm 0.39$ & $34.95 \pm 0.46$ & 0.61 & 0.55 \\
\hline Shank length & $6^{\text {th }}$ & $25.42 \pm 1.32$ & $24.03 \pm 2.30$ & 1.71 & 0.10 \\
\hline Shank width & $8^{\text {th }}$ & $27.96^{\mathrm{a}} \pm 0.49$ & $26.66^{\mathrm{b}} \pm 0.45$ & 2.27 & 0.04 \\
\hline (cm) & $6^{\text {th }}$ & $8.80^{\mathrm{a}} \pm 0.10$ & $7.79^{\mathrm{b}} \pm 0.09$ & 8.56 & 0.00 \\
\hline Keel length $(\mathrm{cm})$ & $8^{\text {th }}$ & $10.34^{\mathrm{a}} \pm 0.10$ & $9.89^{\mathrm{b}} \pm 0.13$ & 2.53 & 0.02 \\
\hline Height $(\mathrm{cm})$ & $6^{\text {th }}$ & $1.56^{\mathrm{a}} \pm 0.04$ & $1.40^{\mathrm{b}} \pm 0.03$ & 3.30 & 0.00 \\
\hline & $8^{\text {th }}$ & $1.62^{\mathrm{a}} \pm 0.03$ & $1.50^{\mathrm{b}} \pm 0.05$ & 2.08 & 0.05 \\
\hline & $6^{\text {th }}$ & $8.68^{\mathrm{a}} \pm 0.11$ & $8.02^{\mathrm{b}} \pm 0.09$ & 5.60 & 0.00 \\
\hline & $8^{\text {th }}$ & $9.75 \pm 0.17$ & $9.37 \pm 0.17$ & 1.44 & 0.17 \\
\hline
\end{tabular}

Means with different superscripts in a row differ significantly $(\mathrm{P} \leq 0.05)$ 
The $8^{\text {th }}$ week cumulative FCR of Native $\times$ CSFL F1 crossbred chicks was found to be 3.23 \pm 0.15 , which was higher than that of Vanaraja (2.16) and Hansli $\times$ CSML (2.26) as reported by Debata et al., (2012) and Ekka et al., (2016) respectively. Padhi et al., (2015) reported $8^{\text {th }}$ week FCR of PD1×PD4 as 2.79 which was also lower than the $8^{\text {th }}$ week FCR of present crossbred chicks. The ability to convert feed in to body mass is dependent on the genotype and the nutrient content of the feed. Therefore, the variability in FCR values as obtained in the present investigation as compared to other crosses could be attributed to these factors.

\section{Body conformation traits}

The body conformation traits of Native $\times$ CSFL F1 crossbred chicks at $6^{\text {th }}$ and $8^{\text {th }}$ weeks of age were presented in Table 4 . At $6^{\text {th }}$ week, only the body girth was not significantly different in male and female chicks and all other linear body measurements were significantly $(\mathrm{P} \leq 0.05)$ higher in males compared to females. At the age of $8^{\text {th }}$ week, head width, body girth, shank length and shank width expressed significant $(\mathrm{P} \leq 0.05)$ difference between male and female chicks and the remaining traits such as breast angle, beak length, keel length and height did not significantly differ in male and female chicks.

The $6^{\text {th }}$ week shank length of both male and female chicks $(8.80 \pm 0.09 \mathrm{~cm}$ and $7.79 \pm 0.09$ $\mathrm{cm})$ was higher than PD1 $\times$ PD4 crosses $(6.66 \pm 1.06 \mathrm{~cm}$ and $6.38 \pm 0.83 \mathrm{~cm})$ as reported by Padhi et al., (2015). However the values obtained were comparable with Hansli $\times$ CSML crosses as reported by Ekka et al., (2016) and also comparable with PD1 $\times$ PB2 crosses $(8.58 \pm 0.62 \mathrm{~cm}$ and $8.08 \pm 0.68 \mathrm{~cm})$ as reported by Padhi et al., (2015). The $8^{\text {th }}$ week conformation traits also revealed similar trend. The keel length of the cross under study at $6^{\text {th }}$ and $8^{\text {th }}$ weeks was also higher than the PD1 $\times$ PD4 crosses as reported by Padhi et al., (2015). The breast angle was higher than Hansli $x$ CSML crosses as reported by Ekka et al., (2016). Ojedapo et al., (2012) reported a positive and significant correlation between body weight and linear body measurements. In the present study, though the $8^{\text {th }}$ week body weight of males was numerically higher than that of females, the difference was not statistically significant. This could be the reason for not obtaining significant difference between most of the linear body measurement parameters of males and females.

Based on the findings of the present experiment, it may be concluded that the high $8^{\text {th }}$ week body weight and low FCR of Native $\times$ CSFL crossbred chicken as well as preferential pricing due to their coloured plumage; the birds could be reared profitably under intensive management system. Further, the cross being developed using local native germplasm, the birds could thrive and perform better in local climatic conditions in rural small scale farming.

\section{Acknowledgments}

The authors are grateful to the All India Coordinated Research Project on Poultry Improvement, Post-Graduate Department of Poultry Science, Orissa University of Agriculture and Technology, Bhubaneswar, Odisha for providing the facilities to carry out this research work.

\section{References}

Adebambo, A.O., Ikeobi, C.O.N., Ozoje, M., and Oduguwa, O.O. 2011. Combining abilities of growth traits among pure and crossbred meat type chickens. Arch. Zootec. 60 (232): 953-963.

Adedokun, S.A., and Sonaiya, E.B. 2002. Crossbreeding Nigeria Indigenous with the Dahlem Red chickens for improved productivity and adaptability. Arch. Tierz. Dummerstorf. 45 (3): 297-305.

AICRP on Poultry Breeding and Poultry Seed Project Annual Report. 2013-2014. Directory of Poultry research ISO90012008, Rajendranagar, Hyderabad.

Chatterjee, R.N., Ahlawat, S.P.S., Yadav, S.P., Senani, S., Kundu, A., Jeya Kumar, S., 
Saha, S.K., Sunder, J., and Bharati, D. 2002.Comparative growth performance of Nicobari fowl and their cost effectiveness under backyard and intensive system. Indian J. Poult. Sci. 37: 63-66.

Debata, D., Panigrahi, B., Panda, N., Pradhan, C.R., Kanungo, S., and Pati, P.K. 2012. Growth performance and carcass traits of Black Rock, Red Cornish and Vanaraja chicken reared in the coastal climatic condition of Odisha. Indian J. Poult. Sci. 47(2): 214-217.

Dwivedi, H.B., Singh, C., and Kushwaha, N.S. 1986. Study on mortality and feed conversion efficiency in inbreds and their crosses. Poultry Guide. 44-47.

Ekka, R., Behura, N.C., Samal, L., Nayak, G.D., Pati, P.K., and Mishra, P.K. 2016. Growth performance and linear body measurements of Hansli, CSML and Hansli $\times$ CSML cross under intensive system of rearing, J Livestock Sci. 7: 114-121.

Jha, D., Prasad, S., Soren, S.K., and Bharti, A. 2013. Production performance of indigenous chicken in intensive farming system. Indian J. Poult. Sci. 48 (1): 105108.

Jha, D.K., and Prasad, S. 2013. Performance of improved varieties and indigenous breed of chicken in Jharkhand. Indian J. Poult. Sci. 48 (1): 109-112.

Jha, D.K., Prasad, S., Soren, S.K., and Mahto, D. 2012. Performance of Vanaraja birds under deep litter system of management. Indian Vet. J. 89 (1): 75-76.

Kalita, N., Pathak, N., and Ahmed, M. 2011. Evaluation of crossbred (PB-2 $\mathrm{x}$ Indigenous) under intensive system of rearing. Indian Poultry Science Association and National Symposium (IPSACON 201213).

Kgwatalala, P.M., and Segokgo, P. 2013. Growth performance of Australorp $\mathrm{x}$ Tswana crossbred chickens under an intensive management system. Int. J. Poult. Sci. 12 (6): 358-361.

Khawaja, T., Khan, S.H., Mukhta, N., and Parveen, A. 2012. Comparative study of growth performance, meat quality and haematological parameters of Fayoumi, Rhode Island Red and their reciprocal crossbred chickens. Italian J. Anim. Sci. 11 (39): 211-216.

Kumerasen, A., Bujarbaruah, K.M. Pathak, K.A., Chhetri, B., Ahmed, S.K., and Haunshi, S. 2008. Analysis of a village chicken production system and performance of improved dual purpose chicken under a subtropical hill agro-ecosystem in India. Tropical Animal Health Prod. 40 (6): 395402.

Nandi, B., Samal, L., Behura, N.C., Nayak, G.D., and Das, D.P. 2017. Growth, efficiency and body conformation traits of Hansli breed of Odisha under intensive management system. J Entomol. Zool. Stud. 5 (6): 23982403.

Ojedapo, L.O., Amao, S.R., Ameen, S.A., Adedeji, T.A., Ogundipe, R.I., and Ige, A.O. 2012. Prediction of body weight and other linear body measurement of two commercial layer strain chickens. Asian J. Anim. Sci., 6: 13-22.

Padhi, M.K., Chatterjee, R.N., and Rajkumar, U. 2014. A study on performance of a crossbred chicken developed using both exotic and indigenous breeds under backyard system of rearing. J. Poult. Sci. Technol. 2 (2): 26-29.

Padhi, M.K., Chatterjee, R.N., Haunshi, S., Rajkumar, U., Niranjan, M., and Rajaravindra, K.S. 2015. Evaluation of four different crossbreds developed for backyard poultry farming under intensive system. Indian J. Anim. Sci. 85 (9): 985-990.

\section{How to cite this article:}

Shyam Sundar Pandey, Nrusingha Charan Behura, Lipismita Samal, Prasad Kumar Pati and Ganga Dhara Nayak. 2018. Evaluation of Juvenile Growth, Feed Efficiency and Body Conformation Traits of Native $\times$ CSFL Crossbred Chicken under Intensive System of Rearing. Int.J.Curr.Microbiol.App.Sci. 7(05): 3370-3376. doi: https://doi.org/10.20546/ijcmas.2018.705.394 